\title{
COMPARATIVE ANALYSIS OF NUTRIENT DIGESTIBILITY AND NITROGEN RETENTION IN WILD AND FARMED CANIDS*
}

\author{
Andrzej Gugołek*, Janusz Strychalski, Małgorzata Konstantynowicz, Cezary Zwoliński \\ Department of Fur-bearing Animal Breeding and Game Management, \\ University of Warmia and Mazury in Olsztyn, Oczapowskiego 5, 10-718 Olsztyn, Poland \\ •Corresponding author: gugolek@uwm.edu.pl
}

\begin{abstract}
The aim of this study, conducted in November 2012, was to determine whether farming of common foxes (Vulpes vulpes) and raccoon dogs (Nyctereutes procyonoides) leads to changes in nutrient digestibility and nitrogen retention in comparison with their wild counterparts. Wild and farmed animals were compared within and between species. Each group consisted of five males and five females aged around eight months. Farmed silver foxes - a variety of the common red fox (group FSF) and farmed raccoon dogs (group FRD) were purchased from a breeding farm in southeastern Poland. Wild red foxes (group WRF) and wild raccoon dogs (group WRD) were trapped in the hunting grounds of the Polish Hunting Association (Olsztyn Division). The animals were placed in metabolism cages. The coefficients of nutrient and energy digestibility, and daily nitrogen balance and retention values were compared between groups. Farmed animals tended to have higher digestibility coefficients than their wild counterparts. No significant differences were noted within species. The coefficients of dry matter $(P \leq \mathbf{0 . 0 1})$, organic matter $(P \leq \mathbf{0 . 0 5}, P \leq \mathbf{0 . 0 5})$ and protein (only FSF vs. WRD - $\mathbf{P} \leq \mathbf{0 . 0 5})$ digestibility were higher in foxes. Raccoon dogs were characterized by higher digestibility of carbohydrates $-\mathrm{N}$-free extracts $(\mathrm{P} \leq \mathbf{0 . 0 1})$. Nitrogen retention was higher in farmed animals. The highest and lowest levels of retained nitrogen were observed in groups FSF and WRD, respectively.
\end{abstract}

Key words: common fox, raccoon dog, feeding, digestibility, $\mathrm{N}$ retention

The family Canidae includes many valuable species of fur-bearing animals such as the common fox (Vulpes vulpes) and the raccoon dog (Nyctereutes procyonoides). According to Statham et al. (2011), the red fox has the widest geographical distribution of all Carnivora species. Numerous red fox subspecies are distributed across Africa, Eurasia, North America and Australia where red foxes became established through successive introductions. Common fox fur farming was pioneered on Prince

\footnotetext{
* This study was financed by the National Centre for Research and Development in Poland, development project No. 12-0140-10.
} 
Edward Island in Southeastern Canada. The original breeding stock included local melanistic foxes (Vulpes v. fulvus) and foxes imported from southern Alaska (Laut, 1921). The red fox subspecies (Vulpes v. crucigera) found in Poland has red-coloured fur. Jeżewska-Witkowska et al. (2012) demonstrated that Polish farmed red foxes originate from the Canadian subspecies and are more closely related to their Canadian ancestors than to wild foxes inhabiting Poland.

The raccoon dog is indigenous to East Asia. Raccoon dogs found in Polish forests are descendants of animals released into the wild in the former USSR (Nowak, 1973; Pitra et al., 2010). The majority of raccoon dogs that are raised on farms in Poland come from raccoon dogs imported from Finland (Barabasz et al., 2011). Ślaska et al. (2010) observed significant genetic differences between farmed and wild raccoon dogs living in Poland.

The Canidae are a family of carnivorous and omnivorous (e.g. raccoon dogs) mammals (Sutor et al., 2010). Nutrient digestibility is determined, among others, by the chemical composition and components of feeds, and the age, species and genetic line of animals. Some species, including raccoon dogs, undergo metabolic changes before winter, and their nutrient digestibility is affected also by the season (Asikainen et al., 2004). Experiments involving members of the families Canidae and Mustelidae (Ahlstrøm and Skrede, 1998; Vhile et al., 2005; Ahlstrøm et al., 2003; Gugołek et al., 2013) revealed differences in the gastrointestinal function between wild and farmed animals. In the cited studies, farm-raised animals were characterized by higher nutrient digestibility and higher nitrogen retention, which points to their higher productivity and suggests that they have become adapted to a wider variety of foods during domestication.

The objective of this study was to compare nutrient and energy digestibility as well as daily nitrogen balance and nitrogen retention in wild and farmed foxes and raccoon dogs.

\section{Material and methods}

The experiment was performed in November 2012, in an experimental shed at the University of Warmia and Mazury in Olsztyn (north-eastern Poland). Farmed silver foxes (a variety of the common fox, a Polish breed line) - group FSF and farmed raccoon dogs (a standard colour variant, the offspring of raccoon dogs imported from Finland) - group FRD were purchased from a breeding farm (included in a recording scheme) in south-eastern Poland. Every animal came from a different litter to ensure representative sampling. Wild red foxes (group WRF) and wild raccoon dogs (group WRD) were harvested (trapped) in the hunting grounds of the Polish Hunting Association (Olsztyn Division). The experiment and the harvesting procedure were approved by the Local Ethics Committee for Animal Experimentation at the University of Warmia and Mazury in Olsztyn, and by the Minister of the Environment.

The animals used in the experiment were born in the spring of 2012, and during the study they were around eight months of age. Each group consisted of five males and five females. 
The animals were fed wet diet for farmed foxes and raccoon dogs, formulated using typical feed components available in Poland (Table 1). The chemical composition, energy value and nutritional value of diet are presented in Table 2.

Table 1. Diet composition (\%)

\begin{tabular}{lc}
\hline \multicolumn{1}{c}{ Ingredients } & $\%$ \\
\hline Hard poultry by-products (heads and legs) & 18.0 \\
Poultry entrails & 31.0 \\
Poultry carcasses & 3.5 \\
Herring by-products & 2.5 \\
Cod by-products & 4.0 \\
Preserved blood & 2.5 \\
Beef offal and slaughter by-products & 5.0 \\
Meat and bone meal & 2.5 \\
Vegetable oil & 1.9 \\
Extruded wheat & 12.0 \\
Green forages, vegetables & 2.0 \\
Vitamin and mineral supplement & 0.1 \\
Water & 15.0 \\
Total & 100.0 \\
\hline
\end{tabular}

Table 2. Chemical composition and nutritional value of diet (\%)

\begin{tabular}{|c|c|}
\hline Item & $\%$ \\
\hline Dry matter & 33.12 \\
\hline Crude ash & 2.46 \\
\hline Organic matter & 30.66 \\
\hline Crude protein & 12.01 \\
\hline Crude fat & 8.64 \\
\hline Crude fibre & 0.69 \\
\hline $\mathrm{N}$-free extract & 9.32 \\
\hline Gross energy $\left(\mathrm{MJ} / \mathrm{kg}^{-1}\right)$ & 7.313 \\
\hline \multicolumn{2}{|l|}{ Energy from: } \\
\hline protein & 31 \\
\hline fat & 49 \\
\hline carbohydrates & 20 \\
\hline metabolizable energy $\left(\mathrm{MJ} / \mathrm{kg}^{-1}\right)$ & 6.303 \\
\hline
\end{tabular}

Table 3. Body weight and body length (mean \pm Sd)

\begin{tabular}{c|c|c|c|c}
\hline \multirow{2}{*}{ Item } & \multicolumn{4}{|c}{ Group } \\
\cline { 2 - 5 } & WRF & FSF & WRD & FRD \\
& $\mathrm{n}=10$ & $\mathrm{n}=10$ & $\mathrm{n}=10$ & $\mathrm{n}=10$ \\
\hline Body weight $(\mathrm{kg})$ & $5.18 \pm 0.60 \mathrm{Bb}$ & $6.87 \pm 0.47 \mathrm{AB}$ & $5.95 \pm 0.69 \mathrm{Ba}$ & $11.77 \pm 0.81 \mathrm{~A}$ \\
Body length $(\mathrm{cm})$ & $64.00 \pm 2.26 \mathrm{Aa}$ & $65.40 \pm 2.50 \mathrm{~A}$ & $56.00 \pm 2.05 \mathrm{~B}$ & $61.90 \pm 1.29 \mathrm{ABb}$ \\
\hline
\end{tabular}

$\mathrm{a}, \mathrm{b}-$ values in rows with different letters differ significantly $(\mathrm{P}<0.05)$.

A, $\mathrm{B}-$ values in rows with different letters differ significantly $(\mathrm{P}<0.01)$.

The harvested animals were kept in standard cages so that they could become adapted to the environmental conditions on the farm. The adaptation period lasted 30 days. Before the experiment, the animals were weighed accurate to $1 \mathrm{~g}$ using 
an electronic scale, and their body length was measured from the tip of the nose to the tail base, accurate to $1 \mathrm{~cm}$ (Table 3). During digestibility and balance trials, the animals were placed in individual metabolism cages $(1 \mathrm{~m} \times 2 \mathrm{~m} \times 0.8 \mathrm{~m})$, equipped for quantitative collection of faeces and urine. A five-day experimental period was preceded by a five-day adaptation period. The animals had free access to water, and they were fed $700 \mathrm{~g}$ of a diet once daily, at the same time. Feed refusals and faeces were collected daily, and weighed accurate to $1 \mathrm{~g}$. Faeces samples were frozen, and faeces and feed samples were partially dried and ground. Urine was preserved with $40 \%$ sulfuric acid, and the volume of the entire urine collection was measured at the end of the experiment. The nutrient content of feed, nutrient excretion in faeces and urinary nitrogen were determined by standard methods (AOAC, 2003). Dry matter content was determined in a laboratory drier at $103^{\circ} \mathrm{C}$. Crude ash content was estimated by sample mineralization in a muffle furnace (Czylok, Poland) at $600^{\circ} \mathrm{C}$. Total nitrogen content was determined by the Kjeldahl method, in the Foss Tecator Kjeltec 2200 Auto Distillation Unit. Ether extract content was estimated by the Soxhlet method, in the Foss Soxtec System 2043. Crude fibre content was determined in the Foss Tecator Fibertec TM 2010 System. The coefficients of nutrient and energy digestibility and nitrogen retention values were calculated using the balance method. Nutrient digestibility was calculated from the formula: WS=a-b/a x 100, where " $a$ " is nutrient intake and " $b$ " is nutrient excretion in faeces.

The data were processed statistically by one-way ANOVA for orthogonal designs, and significance of differences between groups $(\mathrm{P} \leq 0.05, \mathrm{P} \leq 0.01)$ was determined by Duncan multiple range test. The calculations were made with Statistica 10.0 (StatSoft Inc., 2011).

\section{Results}

Table 3 presents the zoometric measurements of experimental animals. The average body weight of wild and farmed foxes reached 5.18 and $6.87 \mathrm{~kg}$, respectively. In raccoon dogs, the respective values were 5.95 and $11.77 \mathrm{~kg}$. Average trunk length in groups FSF and WRF was similar at 64.00 and $65.40 \mathrm{~cm}$, respectively. Average trunk length in groups WRD and FRD reached 56.00 and $61.90 \mathrm{~cm}$, respectively.

The coefficients of nutrient digestibility in wild and farmed foxes and raccoon dogs are shown in Table 4. There were no significant differences between farmed and wild foxes with respect to the digestibility of nutrients and dietary energy. A similar trend was also observed in raccoon dogs. However, it should be noted that the coefficients of nutrient digestibility were higher in farm-raised animals (groups FSF and FRD). Dry matter digestibility was significantly higher $(\mathrm{P} \leq 0.01)$ in foxes of both groups than in raccoon dogs of both groups. Farmed foxes were characterized by the highest level of organic matter utilization (a highly significant difference relative to farmed and wild raccoon dogs). The coefficient of organic matter digestibility was significantly higher in red foxes, compared with farmed $(\mathrm{P} \leq 0.05)$ and wild raccoon dogs $(\mathrm{P} \leq 0.01)$. There was a significant difference of 1.49 percentage units in 
total protein digestibility between farmed foxes and wild raccoon dogs. Crude fat digestibility was similar in all groups. Raccoon dogs were characterized by higher digestibility of carbohydrates. The noted difference between foxes and raccoon dogs reached 10 percentage units (including crude fibre and nitrogen-free extracts). Dietary energy digestibility remained at a similar level in all groups, ranging from 86.01 in group WRF to 89.32 in group FRD.

Table 4. Nutrient and energy digestibility (mean \pm Sd)

\begin{tabular}{l|c|c|c|c}
\hline \multirow{2}{*}{\multicolumn{1}{c}{ Item }} & \multicolumn{4}{c}{ Group } \\
\cline { 2 - 5 } & \multicolumn{1}{c}{$\begin{array}{c}\text { WRF } \\
\mathrm{n}=10\end{array}$} & $\begin{array}{c}\text { FSF } \\
\mathrm{n}=10\end{array}$ & $\begin{array}{c}\text { WRD } \\
\mathrm{n}=10\end{array}$ & $\begin{array}{c}\text { FRD } \\
\mathrm{n}=10\end{array}$ \\
\hline Dry matter (\%) & $81.69 \pm 1.56 \mathrm{~A}$ & $82.52 \pm 2.61 \mathrm{~A}$ & $76.24 \pm 4.08 \mathrm{~B}$ & $77.78 \pm 2.17 \mathrm{~B}$ \\
Organic matter (\%) & $87.45 \pm 0.99 \mathrm{Ca}$ & $88.12 \pm 1.88 \mathrm{~A}$ & $84.24 \pm 2.53 \mathrm{BD}$ & $85.35 \pm 1.59 \mathrm{Bb}$ \\
Total protein (\%) & $90.38 \pm 0.91$ & $90.52 \pm 1.43 \mathrm{a}$ & $89.03 \pm 1.77 \mathrm{~b}$ & $89.85 \pm 1.70$ \\
Crude fat (\%) & $99.36 \pm 0.18$ & $99.40 \pm 0.09$ & $99.33 \pm 0.24$ & $99.33 \pm 0.26$ \\
Crude fibre (\%) & $19.86 \pm 11.27 \mathrm{~B}$ & $20.65 \pm 9.30 \mathrm{~B}$ & $28.43 \pm 13.81$ & $37.28 \pm 8.35 \mathrm{~A}$ \\
N-free extracts (\%) & $57.81 \pm 6.65 \mathrm{~B}$ & $60.15 \pm 4.99 \mathrm{~B}$ & $68.98 \pm 4.07 \mathrm{~A}$ & $71.49 \pm 5.56 \mathrm{~A}$ \\
Gross energy (\%) & $86.01 \pm 4.19$ & $86.31 \pm 3.72$ & $87.96 \pm 3.84$ & $89.32 \pm 2.15$ \\
\hline
\end{tabular}

$\mathrm{a}, \mathrm{b}-$ values in rows with different letters differ significantly $(\mathrm{P}<0.05)$.

A, B; C, D - values in rows with different letters differ significantly $(\mathrm{P}<0.01)$.

Table 5. Daily nitrogen balance and nitrogen retention (mean $\pm \mathrm{Sd})$

\begin{tabular}{l|c|c|c|c}
\hline \multirow{2}{*}{\multicolumn{1}{c}{ Item }} & \multicolumn{4}{c}{ Group } \\
\cline { 2 - 5 } & $\begin{array}{c}\text { WRF } \\
\mathrm{n}=10\end{array}$ & $\begin{array}{c}\text { FSF } \\
\mathrm{n}=10\end{array}$ & $\begin{array}{c}\text { WRD } \\
\mathrm{n}=10\end{array}$ & $\begin{array}{c}\text { FRD } \\
\mathrm{n}=10\end{array}$ \\
\hline $\mathrm{N}$ intake $(\mathrm{g})$ & $7.98 \pm 0.28$ & $8.11 \pm 0.10$ & $7.67 \pm 1.09$ & $8.01 \pm 1.42$ \\
Faecal N $(\mathrm{g})$ & $0.77 \pm 0.09$ & $0.77 \pm 0.11$ & $0.75 \pm 0.19$ & $0.66 \pm 0.13$ \\
Urinary N $(\mathrm{g})$ & $5.33 \pm 0.40$ & $5.06 \pm 0.58$ & $5.20 \pm 0.79$ & $5.15 \pm 1.00$ \\
Digested $\mathrm{N}(\mathrm{g})$ & $7.21 \pm 0.25$ & $7.34 \pm 0.15$ & $6.92 \pm 0.95$ & $7.35 \pm 1.31$ \\
Retained $\mathrm{N}(\mathrm{g})$ & $1.88 \pm 0.44$ & $2.28 \pm 0.63 \mathrm{a}$ & $1.72 \pm 0.64 \mathrm{~b}$ & $2.20 \pm 0.42$ \\
$\mathrm{~N}$ retention as \% of N intake & $23.55 \pm 5.23$ & $28.12 \pm 7.60$ & $22.36 \pm 6.89$ & $27.53 \pm 3.36$ \\
$\mathrm{~N}$ retention as \% of digested $\mathrm{N}$ & $26.04 \pm 5.69$ & $31.04 \pm 8.31$ & $24.75 \pm 7.58$ & $30.01 \pm 3.62$ \\
\hline
\end{tabular}

$\mathrm{a}, \mathrm{b}-$ values in rows with different letters differ significantly $(\mathrm{P}<0.05)$.

Table 5 presents daily nitrogen balance and nitrogen retention in farmed and wild foxes and raccoon dogs. Nitrogen retention values, as \% of $\mathrm{N}$ intake and $\mathrm{N}$ digested, were approx. $5 \%$ higher in farmed animals, but there were no significant differences between groups. 


\section{Discussion}

The body weights of farm-raised foxes and raccoon dogs were significantly higher than the body weights of their wild counterparts (Table 3). A higher difference in body weight was noted between farmed and wild raccoon dogs $(5.82 \mathrm{~kg})$.

In Poland, the average body weight of captive-bred foxes ranges from $7.4 \mathrm{~kg}$ in males to $6.1 \mathrm{~kg}$ in females (Lorek et al., 2001). The body weights of wild adult foxes hunter-harvested in Poland in the fall/winter seasons of 1997-2007 ranged from 5.45 to $6.58 \mathrm{~kg}$, and the body weight of young foxes during this period reached 4.52-5.76 kg (Tryjanowski et al., 2009) and $5.4 \mathrm{~kg}$ (Kalisińska et al., 2012). Raccoon dogs bred in captivity in Poland are the offspring of animals imported from Finland. According to Barabasz et al. (2011), their average body weight is $10-12 \mathrm{~kg}$, but it may vary among lines. Liu et al. (2012) reported that raccoon dogs farmed in Asia have body weights of 6.79 to $7.57 \mathrm{~kg}$, while according to Zhang et al. (2012) their body weights determined in September were $4.55-5.33 \mathrm{~kg}$.

Differences in trunk length between wild and farmed foxes and raccoon dogs were smaller than differences in their body weight. Higher body weights of farmraised animals resulted from their stronger constitution and fat deposition. According to Lorek et al. (2001), the trunk length of male and female foxes bred in captivity in Poland ranges from 59 to $82 \mathrm{~cm}$ (72 cm on average), and from 59 to $79 \mathrm{~cm}(67 \mathrm{~cm}$ on average), respectively. Kalisińska et al. (2012) reported that the average trunk length of wild red foxes was $65 \mathrm{~cm}$. According to Kulawik et al. (2009), the average trunk length of female raccoon dogs is $64 \mathrm{~cm}$.

There were no significant differences in nutrient digestibility between farmed and wild foxes (Table 4), which indicates that there has not been any significant change in their digestive system over 100 years of breeding. However, in contrast to arctic foxes, captive-bred silver foxes have always been fed a typical carnivorous diet, and no attempts have been made to increase carbohydrate concentrations in their ration (Ahlstrøm and Skrede, 1998). To date, studies of nutrient digestibility in foxes have tended to focus on arctic foxes rather than farmed common foxes, most probably due to the excitable behaviour of the latter. Faulkner et al. (1992) and Faulkner and Anderson (2001) determined nutrient digestibility in adult silver foxes fed a basal diet and the calculated digestion coefficients for dry matter and protein reached $81 \%$ and $89 \%$, respectively.

The nutrition of farmed raccoon dogs remains poorly investigated compared with foxes. Asikainen et al. (2004) observed seasonal variations in the physiology of wild raccoon dogs. There are only a few studies that evaluate nutrient digestibility in farmed raccoon dogs. The coefficients of nutrient digestibility in farmed raccoon dogs aged 3.5 and 6 months, calculated by Bieguszewski and Lorek (1986) were as follows: organic matter -80 and $86 \%$, total protein -82 and $91 \%$, fat -89 and $98 \%$, nitrogen-free extracts -65 and $66 \%$, respectively. The values reported for six-month-old raccoon dogs in the above study are similar to those obtained in our experiment. A study by Liu et al. (2012), conducted in September, revealed that nutrient digestibility varied considerably depending on the diet. The digestibility of dry matter ranged from 68 to $77 \%$, of protein - from 67 to $73 \%$, and of fat - from 69 to 
$78 \%$. In a study by Zhang et al. (2012), the digestion coefficients were $61-74 \%$ for dry matter, $64-78 \%$ for protein, and $60-72 \%$ for fat.

The differences in carbohydrate digestibility between foxes and raccoon dogs are due to the fact than raccoon dogs are not typical carnivores - they are considered an omnivorous species. A higher proportion of plant components in the diet has been found to improve the production performance of farm-raised animals (Lorek and Gugołek, 1993).

In the present study, farmed animals were characterized by higher levels of nitrogen retention, calculated as $\%$ of $\mathrm{N}$ intake and $\mathrm{N}$ digested (Table 5), which could result from selection for higher productivity. Animals raised for fur are selected for a thick fur coat and increased body size, which is correlated with higher efficiency of the digestive tract and a faster metabolic rate. Our results are consistent with nitrogen retention values reported for another species of fur-bearing animals - the mink (Gugołek et al., 2013).

It should be noted that nitrogen retention was low in all groups. An absence of differences in daily nitrogen balance and nitrogen retention between farmed and wild foxes and raccoon dogs could be due to the fact that our study was conducted in November, i.e. after cessation of growth. Bieguszewski and Lorek (1986) reported a higher level of nitrogen retention as $\%$ of $\mathrm{N}$ intake in raccoon dogs aged six months (35-36\%). Zhang et al. (2012) demonstrated that nitrogen retention as \% of $\mathrm{N}$ intake in growing raccoon dogs may vary from 27 to $54 \%$ depending on the dietary inclusion levels of essential amino acids, lysine and methionine.

The results of our study show that farmed animals tended to have higher digestibility coefficients than their wild counterparts. No significant differences were noted within species. The coefficients of dry matter, organic matter and protein digestibility were higher in foxes. Raccoon dogs were characterized by higher digestibility of carbohydrates (crude fibre and nitrogen-free extracts). Nitrogen retention was higher in farmed animals. The highest and lowest levels of retained nitrogen were observed in groups FSF and WRD, respectively.

\section{References}

A h 1 s trø $\varnothing$ Ø., S k re d e A. (1998). Comparative nutrient digestibility in dogs, blue foxes, minks and rats. J. Nutr., 128: 2676-2677.

A h 1 strøm Ø., F u g l e i E., M y d l and L. (2003). Comparative nutrient digestibility of arctic foxes (Alopex lagopus) on Svalbald and farm-raised fox (Alopex lagopus). Comp. Bioch. Physiol. Part A., 134: 63-68.

AOAC (2003). Official Methods of Analysis of the Association of Official Analytical Chemists, Ed. 17, Arlington, p. 684.

A s i ka in en J., Must on en A.M., Hy varin r n H., N i e min en P. (2004). Seasonal physiology of wild raccoon dog (Nyctereutes procyonoides). Zool. Sci., 21: 385-391.

B arabasz B., Łapiński S., Fortuńska D. (2011). Productive value of Finn raccoons (Nyctereutes procyonoides, Gray 1834) with confident temperament. Ann. Anim. Sci., 11: 165-170.

B i e guszewski H., L orek M.O. (1986). The digestibility of nutrients and nitrogen retention in raccoon dogs (Nyctereutes procyonoides Gray) (in Polish). Zesz. Nauk. ATR Bydgoszcz, Zootechnika, 140: 5-9. 
F a u $1 \mathrm{kn}$ e r W.L., A n d e r s o n D.M. (2001). The effect of fiber supplementation on diet digestibility by silver foxes. Can. J. Anim. Sci., 71: 943-947.

F a u $1 \mathrm{kn}$ e r W.L., E g a n L.A., A n d e r s o n D.M. (1992). Apparent and true digestibility of dry matter, crude protein and amino acids in diets for mature silver foxes. Norw. J. Agric. Sci., Suppl., 9: $268-274$.

Gugołek A., Zalewski D., Strychalski J., Konstantynowicz M. (2013). Food transit time, nutrient digestibility and nitrogen retention in farmed and feral American mink (Neovison vison) - a comparative analysis. J. Anim. Physiol. Anim. Nutr., 97: 1030-1035, DOI: 10.1111/ jpn. 12006.

Jeżewska-Witkowska G., Horecka B., Jakubczak A., Kas perek K., Ślaska G., Bugno-Poniewierska M., Piórkowska M. (2012). Genetic variability of farmed and free-living populations of red foxes (Vulpes vulpes). Ann. Anim. Sci., 12: 501-512.

K a lis ińs k a E., L i s o w s ki P., K o s i k - B o g a c k a D.I. (2012). Red fox Vulpes vulpes (L., 1758) as bioindicator of mercury contamination in terrestrial ecosystems of north-western Poland. Biol. Trace Elem. Res., 145: 172-180.

K u lawik M., Frą ck ow i a k H., J a k ub ow ski H. (2009). Morphometry of intestines of the raccoon dog (Nyctereutes procyonides). Acta Sci. Pol.-Med. Vet., 8: 3-8.

L a u t A.C. (1921). The fur trade of America. New York. USA. Macmillan Company, New York, p. 341 .

L i u H., Li G., Zhong W., Li D., Li u F., S un W. (2012). Supplemental dietary methionine affects the pelt quality and nutrient metabolism of raccoon dogs (Nyctereutes procyonoides). Asian J. Anim. Vet. Adv., 7: 61-67.

L o r e k M.O., G u g ołe k A. (1993). The effect of different diets on reproductive performance of raccoon dogs. Scientifur, 3: 207-210.

L or ek M.O., Gugołek A., Hartman A. (2001). Studies on relationship between body weight, trunk length and pelt size in common fox (Vulpes vulpes). Czech J. Anim. Sci., 46: 481-484.

N ow a k E. (1973). Ansiedlung und Ausbreitung des Marderhundes (Nyctereutes procyonides Gray) in Europe. Beitr Jagd. Wildforschung, VIII: 351-384.

P itra C., S c hwarz S., F i c k e l J. (2010). Going west: invasion genetics of the alien raccoon dog Nyctereutes procyonoides in Europe. Eur. J. Wildl. Res., 56: 117-129.

S t a th a m M.J., Trut L.N., S a c k s B.N., K har la mova A.V., O s k in a I.N., Gu levich R.G., Johns on J.L., Temnykh S.V., A c land G.M., Kukekova A.V. (2011). On the origin of a domesticated species: identifying the parent population of Russian silver foxes (Vulpes vulpes). Biol. J. Linn. Soc., 103: 168-175.

Sutor A., Kauhala K., A n s orge H. (2010). Diet of raccoon dog (Nyctereutes procyonoides) a canid with an opportunistic foraging strategy. Acta Theriol., 55: 165-176.

Ślaska B., Zięba G., Rozempolska-Rucińska I., Jeżewska-Witkowska G., J a k u b c z a k A. (2010). Evaluation of genetic biodiversity in farm-bred and wild raccoon dogs in Poland. Folia Biol. (Kraków), 58: 195-199.

Tryja now s ki P., S p ark s T.H., K a m i e n i ar z R., P a n e k M. (2009). The relationship between hunting methods and sex, age and body weight in non-trophy animal, the red fox. Wildlife Res., 36: $106-109$.

Vhile S.G., S k re de A., A h 1 s t r ø m Ø., H o ve K. (2005). Comparative apparent total tract digestibulity of major nutrients and amino acids in dogs (Canis familiaris), blue foxes (Alopex lagopus) and mink (Mustela vison). Anim. Sci., 81: 141-148.

Zh a n g H.H., Yu e A.G., L i u F.H., C a o X.Y., Yang F.H., L i G.Y. (2012). Effect of growth performance and N-balance of growing raccoon dogs fed reduced crude protein, lysine and dl-methionine supplementation diets. J. Anim. Vet. Adv., 11: 2187-2190.

Received: 5 VI 2013

Accepted: 8 VIII 2013 